
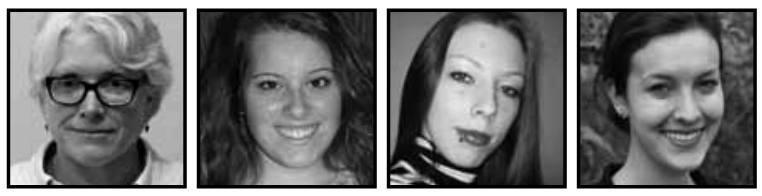

\title{
Debate, Deliberation, Design, and Delivery: Deciding (Whether or) Not to Go by the Book
}

\author{
Michele Pinard, Gina Marie Bilardi, Donna Cappel, \\ and Kathy Irwin, State University at New York, Potsdam
}

\section{ABSTRACT}

This article shares one junior faculty member's account of how she and her students debated, deliberated about, decided to, and ultimately reshaped a traditional, foundational Principles of Education course in an undergraduate teacher education program. Three former childhood, art, and theater education students highlight their experiences, observing connections between their own and their instructor's creativity and evolving philosophies of education. Together, they illustrate issues they confronted while reflecting individually and collectively on how and whether to creatively teach and learn, while also being constrained by practical, systemic realities.

\section{Debate}

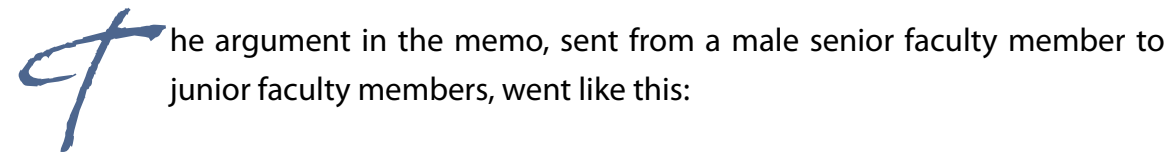

...students are much too quick to want a personal philosophy,...l worry about the conflation of a 'personal' philosophy with a developed philosophy of education. It isn't that they aren't connected, but that an examination of the latter should precede the development of the former. That is, any personal philosophy should be the result of first studying what experts have had to say about the issues important to a philosophy of education... (Correspondence from PI Committee Member to C\&I EDLS 201 Revision Committee Members, Fall 2010) 
No amount of discussion when the curriculum review committee met could persuade senior faculty that students' arrival with pre-formed "philosophies" of education could be points of departure for straying from descriptors attached to course curricula designated in the General Education as "Philsophical Inquiry" (PI). Perennially oriented, the dominant opinion was that students' experiences should be relegated secondary to classic thinkers'; junior approaches were dismissed as being imprudent:

...philosophy is far too important to be left to the philosophers, and, in addition, is essentially interdisciplinary in nature... this doesn't excuse folks from engaging with what experts in the field have had to say about the important philosophical issues, and it seems to me that an introductory philosophy course should largely be an introduction to what some of those experts have had to say.... (Correspondence from PI Committee Member to C\&I EDLS 201 Revision Committee Members, Fall 2010)

This debate, ironically, might have been exactly the opposite twenty years earlier when 1990s P-16 educators were initially asked to respond to globalization. Innovation, creativity, and "lifewide" creativity were being applied broadly and increasingly valued (Craft, 2003). Educators were responsible for contributing to economic advancement. Today, notions of what creativity is or could be remains a topic of philosophical debate; though this is not this article's core focus, increasingly, it has become apparent in the U.S. education system that counterpoint voices supporting arts-based learning and alternative pedagogies or assessment forms have dwindled. New York State educators at all levels are under federal pressure to "Race to the Top." Annual performance program reviews (APPR) depend on models such as Danielson's Framework for Teaching (2011) in which "creativity" is to be demonstrated at proficient and distinguished levels by teachers; otherwise, one might be judged as incompetenteven dismissed, despite being tenured. Resources and funds available for Science, Technology, Engineering, and Mathematics (STEM) programs increase the need for evidence in the accountability movement. Standardized instruction and evaluation force documentation of quantifiable rather than qualitative outcomes. Widespread pressures, from early childhood throughout teacher preparation programs, literally force time for creativity out of prescribed curricula.

At SUNY Potsdam in the School of Education \& Professional Studies, this junior faculty author and her co-author students teach and learn amidst this pressure. SUNY Potsdam accounts for student outcomes, primarily, by submitting quantitative reports to the National Council for Accreditation of Teacher Education (NCATE) through an electronic portfolio system (TaskStream taskstream.com). Teacher 
education candidates' dispositions, or "soft skills," are documented in seven broad areas, primarily in two dimensions: how candidates are "willing to take risks and show comfort with uncertainty" and when they "recognize and respect one's own diversity and that of others." Indicators show that a candidate: "tries unfamiliar techniques, encourages students/peers in taking risks, uses instructional resources that incorporate or depict alternative points of view, uses instructional practices that respects/ reflect diversity among participants, (and) seeks divergent points of view" (CE/EC Dispositions, 2009, SUNY Potsdam). Students are required to earn three credits in the aesthetic experiential $(\mathrm{AE})$ mode and three in the aesthetic in the critical and discriminative $(A C)$ domains of the general education curriculum (http://www.potsdam.edu/ academics/general_education/moi/index.cfm). Art education and theater education majors are exposed by nature to creative pedagogy. Childhood and early childhood students also take a course in Creative and Sensory Experiences (Birth-Grade 2).

Specific definitions about what it means to be "creative" have shifted since 1990 to include valuing: ordinary people rather than genius; process versus product; and, qualitative characteristics more than quantitative measurements (Craft, 2003). Culture-specific values, as well as policies and practices within formal and informal education settings, practically influence how teachers are able to enact their philosophies of education. Junior faculty members (without tenure, such as I was at the time) may succumb to social limitations, however, to avoid political sanctions; instructors may become socialized into submission, or experience suffocation of their creativity (Craft, 2003).

Senior faculty rebukes (such as those in the memo) clearly revitalized the creativity debate:

...the obvious tension between...the idea of the concept of creativity being at all limited is paradoxical in itself. For it would seem that creativity is an open-ended concept, concerned with the development and application of possibilities - and thus inherently unlimited. (Craft, 2003, pp. 117-118)

My relative confidence in unorthodox teaching methods did little to stave off senior faculty members' scrutiny or attempts to squelch my choices of materials. The debate about EDLS course design, purposefully chosen arts-based exercises and non-western readings, intentionally attempting to expand students' philosophical understanding of what it means to teach, learn, and serve in diverse educational communities conflicted with my belief that philosophy is and should remain a topic of unresolved (and personal) exploration. 


\section{Deliberation}

More pragmatic issues centered on getting the syllabus approved. I suspected my primal reaction to being thwarted was not unfamiliar to veteran educators. Although our department had provenance over this course, it appeared that less robust syllabi retained the "PI" designator, for instance. Nevertheless, students enroll in foundational classes prior to methods or fieldwork courses. Central outcomes are supposed to focus on contextualizing philosophies historically; students are expected to synthesize and articulate evolutionary, professional teaching philosophies. Creatively demonstrating understanding of core PI concepts did not appear incompatible to me with philosophical inquiry.

Among faculty within the Curriculum \& Instruction (C\&l) department assigned to tweak the syllabus during the renewal process, I took a less essentialist and perennial approach than previous instructors. Revisions reflected studentcentered, constructivist, critical, and comparative theoretical approaches; I wanted students to be creative and to take risks by producing arts-based rather than solely text-based conceptualizations of their philosophies. Unfortunately, these brought our syllabus under close scrutiny. There appeared to be a fundamental dispute about how (or whether) junior faculty should be allowed to (creatively) teach the course, a discussion Kenkmann (2008) describes is increasingly occurring in adult education and higher education circles, though rarely about philosophy courses. However, inhibiting teachers' and students' creativity by centrally controlling content and teaching-learning strategies or, supporting it by appropriate organizational climates (Craft, 2003) fundamentally reflects an institution's values and is demonstrated by these actions. This ultimately serves to diminish or enhance teachers' and learners' self-efficacy, as well as to force convergent or nurture divergent thought (Fasko, 20002001). It was this realization that most upset me.

The C\&I team (and I) interpreted the curriculum committee's criticism to mean that "expert voices" should outshout students.' Our debates centered on whether best approaches should be inductive or deductive. Differences became painfully obvious when readings and assignments were closely scrutinized. Nowhere on the list of philosophers we were urged to consider was a female or non-Western thinker, for instance, though text (Parkay \& Stanford, 2010) and anthology (Chartock, 2004) readings approved previously contained excerpted references of each. Non- "classic" (e.g., Freire, 2005; Reagan, 2005) selections were now criticized as straying into "XC" (crosscultural) designator territory. These criticisms reflect what Craft identified as two of the dangers of complacent and resistance approaches to curricula. The first indicates that, "...we have a curriculum and a framework which acknowledges creativity and 
which connects creativity - ...so we need do nothing else than implement the curriculum as if it were unproblematic" (2003, p. 124). To temper this criticism, we C\&l educators attempted to adopt "alternative assignments" suggested: an argumentative paper, a counter-argumentative paper, and a counter-counter argumentative paper. Oh-and one debate. In other words — retreads of traditional means of "philosophical inquiry." Craft's second position is that educators who implement creative approaches are polarized and represent "the Other." Tensions between members of the curriculum committee, represented solely by faculty from the School of Arts \& Science, versus the School of Education \& Professional Studies, clearly surfaced during our curriculum review process. These tensions were overt and went unresolved; we felt viewed as "the Other" - as marginalized, less competent, strange and deficient in our worldviews about, ironically, curriculum and instruction-our supposed area of expertise. When the EDLS 201 course syllabus ultimately did not receive a PI designator, education students were made exempt from earning PI General Education credit to graduate. The temporary "solution" did not, in my opinion, resolve the deeper issues - which were in large part about creative license to demonstrate teaching and learning processes.

\section{Design}

My reaction to centering students' experiences primarily in text, in verbal and written (or other linguistic forms of) debate was firm. Arts-based means of processing students' lived school experiences became a way of encouraging them to examine socio-cultural shaping by their families', teachers', schools', religions', and communities' educational values_-prior to bringing out the "experts." These aligned with fundamental objectives of the course syllabus, which claimed to examine:

1. the nature of knowledge as it applies to the education profession

2. the metaphysical, epistemological, and axiological underpinnings of prominent educational philosophies and philosophers associated with each

3. how philosophies of educators materialize as goals and objectives within historical eras, political communities, and as socio-economic conditions change

Arts-based or non-western based "ways of knowing" were not mutually exclusive with these objectives. I was, at the time, in the midst of doctoral studies, and had experienced my own philosophical epiphanies through non-traditional means; perhaps this is why I was less willing to compromise: in spite of extensive experience as a classroom teacher, I was, still more idealistic —even as a junior faculty member. Immersed in examining narratives and critical incidences, using self-study methodology, I was committed to the philosophy that students' life experiences mattered. 
Post-modernism came alive for me in arts-based classroom exercises such as Readers' Theater, found poetry, and collage. Teachers formally liberated the thought that students' voices or "ways of knowing" count! These ideas lucidly emerged through arts-informed exercises in an interpretive inquiry course (Butler-Kisber, 2010) and collage exercises; as Gunn (2010) points out, philosophical inquiry is both about skill development and knowledge acquisition. I was hoping to re-create this in EDLS 201: I wanted students to creatively explore what it means to teach, learn, and serve. Influenced by idealist, progressivist, pragmatist, realist, social reconstructionist, critical theorist, and feminist readings and activities-I hoped students would demonstrate a personal (albeit emerging) understanding of philosophy of education by creative means. I believed students could (or should) mine personal experiences first, begin to analyze primordial influences, and determine for themselves how viewpoints about teaching, disciplining or managing students, or manipulating curricula are affected. Essentially, I wanted to empower students to challenge status quo and find alternative modes of existence (of thought) or ways of demonstrating their knowing (Craft, 2003). It was disheartening to me that a course review committee would co-opt a colleague's philosophy so fundamentally. As students in my sections were slated to become certified early childhood, childhood, and secondary teachers, as well as theater and art education majors, I could not envision being philosophical just by "thinking" rather than by "doing" (Kenkmann, 2008); instead, I found 25 ways to develop creativity by Sternberg and Williams (as described in Fasko, 2000-2001) to be a useful conceptual guide in choosing strategies, as my students' multiple learning styles (and certification tracks) would certainly demand active approaches.

\section{Delivery}

As an operational premise for EDLS 201, I decided students should focus on life histories. Narrative inquiry approaches supplemented graphic representations. I shared collage and mixed methods to contextualize autobiographical information and revealed what values, experiences, and struggles in life impacted my own teaching and learning. I encouraged students to explore media and began overtly provoking assumptions around other students' and teachers' ideas (using text readings as a backdrop). I asked students to question typical research notions of objectivity, whether there differences exist between the researcher and the researched, etcetera. Melding auto ethnographic traditions with self-study, I shared my own research, noting how critical incidences centered on "epiphanal event(s)" (Denzin, 1989) and "turning point(s)" (McAdams, Josselson, \& Lieblich, 2001 in Chase, 2005, p. 652).

Reactions to using creative methods or forms of assessment in this course were not always immediately warm, comprehensive, or accepting. Many students 
stuck with papers, for instance, while a few created posters, and one or two created web-based versions of their lives set to music using Garage Band. To encourage risk-taking, I tinkered with rubric language about the "creative" elements. Students ventured further and produced more aesthetically pleasing and thought-provoking pieces. Over time, students have warmed to using non-text based means to represent autobiographies. Gaining permission to showcase examples of previous students' work, I bring in examples of alternate means of representing life stories-one friend's non-traditional "tea-box" representing her child's birth announcement, or drawing from the respectable collection of student-donated samples (of quality and sub-standard work). Both are instructive. Displaying students' work (along with the rubrics) to assess, prior to assigning projects, allows me to discourage mimicry, encourage originality, and, though I get some of the former, I long for more of the latter. Students' work becomes inspirational, I find, when student-centered versus teacher-centered instruction occurs. Learning becomes reciprocal and integral to my own teachinglearning process and launches a ripple effect among students.

One piece that always captures students' imaginations is a painting (Fig. 1) of a student's "inner eyes"; in this, unique differences between existentialist and essentialist paths that a novice teacher found herself considering are encapsulated.

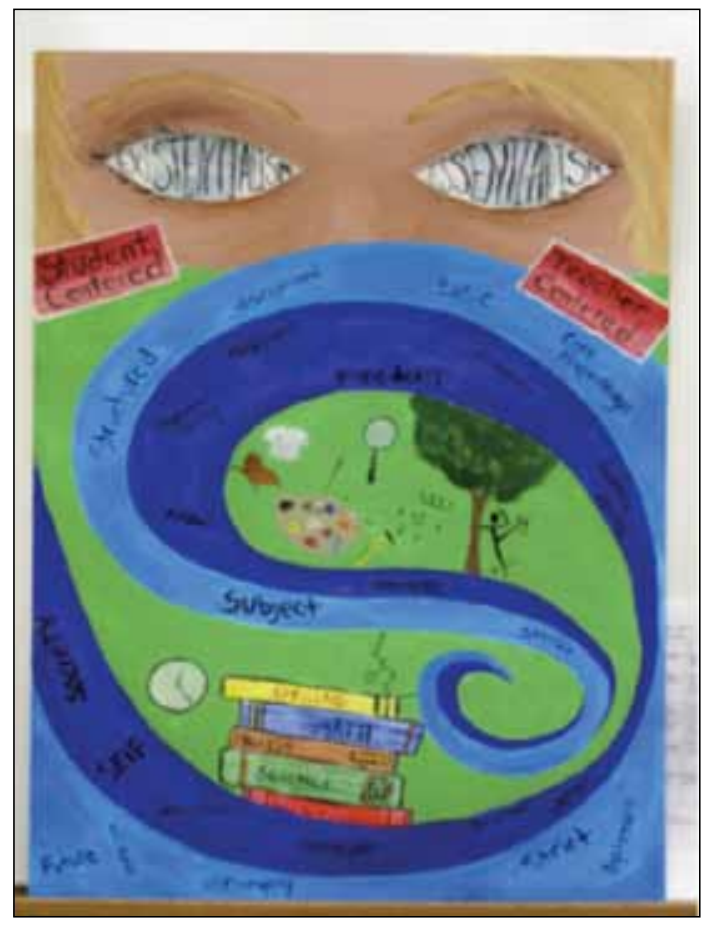

Fig. 1: J. Robinson, May 2011 (Used with permission of artist) 
Novice teacher candidates instantaneously relate to this artist's dilemma, as my veteran colleagues also do. They imagine traipsing along, pondering how best to nurture students' love for learning. Even as a seasoned faculty member, I acknowledge the invisible power I wield. I wrestle often with how best to guide students to uncover their philosophies of education without authoritatively imposing my own. This student artist captured this dilemma in the piercing eyes. Philosophical decisions about teaching go to the heart of creativity when designing curriculum, crafting choices about how to teach, so that students can best learn and we best serve a community.

\section{Deciding (whether or not) to go by the book.}

My overall attempts to nurture creative displays or personalized educational philosophies have included social justice through the arts, but these elicit mixed reactions from students who are not used to nor comfortable with alternative classroom structures. Some students prefer traditional, lecture-based and objective assessments. With less faith in "radical" or "ambiguous" methods, they make their discomfort known. While I am comfortable with their discomfort, they clearly are not. Heightened political implications of being untenured in education contexts have made me apprehensive about leading students astray or too far from "schools" of thought and expectations, as well. As I have been reluctant to purposefully offend senior faculty, I also worry about preparing students to confront harsher evaluation processes. I am not completely naïve about reappointment or about consequences of disregarding judgments of one's "teaching effectiveness."

Kress (2010) vocalized how ambivalent attempts to motivate creativity may result (inadvertently) in alienating students, describing them within the conceptual framework of post formalism, and recalling the theoretical process of bricolage presented by Maxine Greene (1988). Cook, Smagorinksy, Fry, Konopak, and Moore discussed Problems in Developing a Constructivist Approach to Teaching (2002) and the fundamental disconnect in teacher education programs between how concepts are defined (or not) and modeled (or not), as well as how students appropriate them. When creativity as a concept is vague, not valued within education, or is marginalized, at best, within educational institutions, students and teachers lack power to unleash full potential to solve problems or create new knowledge. In a global and diverse information society, we depend on innovation to advance our economy. The role of creativity and STEM fields are not mutually exclusive. Building disciplined innovation through lesson structures that scaffold learning experiences in teacher education programs (Sawyer, 2006) would appear to be a promising way of addressing creativity. 


\section{The students' view.}

I turn now to students to reveal their experiences in EDLS 201. Donna, Gina, and Kathy lend their creative voices and share how they creatively explored core course concepts.

Donna is a first generation high school and college graduate; her confidence and willingness to take risks socially caught my attention in the first few EDLS 201 classes. Raised in Florida, she struggled in public schools, and gained success after moving to New York by enrolling in regional vocational Board of Cooperative Educational Services (BOCES) programs and studying at the Long Island High School for the Arts. At SUNY Potsdam, Donna's academic skills continued to be bolstered by involvement in the Educational Opportunity Program (EOP) (http://www.potsdam.edu/support/ eop/index.cfm). Donna's goal was to become an art teacher, concentrating on Studio media, Advanced Drawing and Painting and Digital Photography. Donna framed my instructional approach as "student centered with a focus on ...choice theory... leaving room for flexibility to meet the needs of the students..." She claimed this affected her learning due to the "flexibility in class structure as well as (the) teaching approach...(it) open(ed) doors for me and allowed me to take risks and be creative... (allowing) me to respond artistically in an academic setting." In this photo essay (Fig. 2), Donna imagined herself as a (student) teacher:

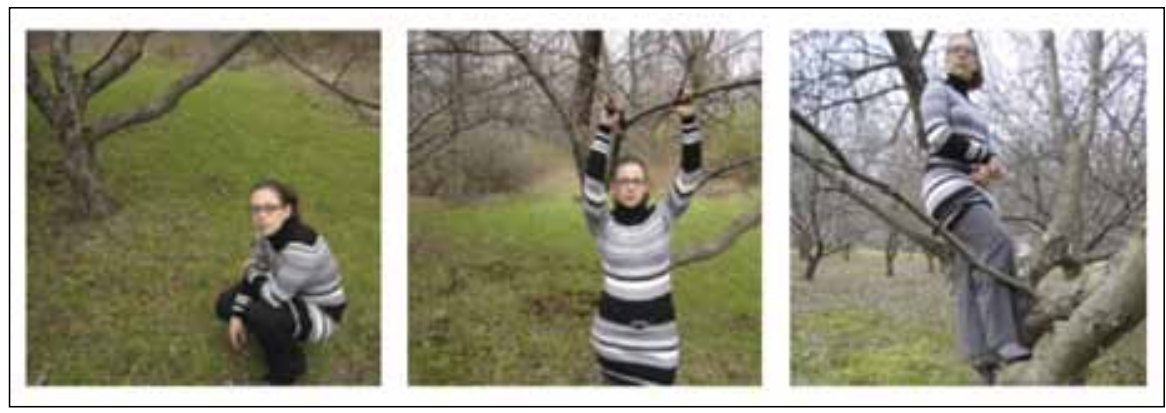

Fig. 2: Donna Cappel - Imagining self as a student teacher

Donna elaborated on how her creative images reflect her professional dispositions, philosophy of education and classroom management style, enabling me to evaluate connections she made with course content:

...The first image represents auditory learning, the second is tactile/kinesthetic learning and the last is visual learning....An analogy that can help to 
explain the auditory pose is when you go hunting, you crouch down to listen to the deer approaching. Just like hunting, a teacher needs to get down to the students' level and listen. The tactile/kinesthetic pose has hands-on experience [as my] touching the branches of the tree is symbolic of how teachers touch the lives of their students. Finally the visual learning style is represented with me up in a tree looking out onto the horizon because not everything can be touched or heard, but has to be seen as well. I incorporated all three learning styles into every lesson that I create in order to fit the needs of every student... These images also support the nature vs nurture debate to teaching... As every good teacher knows, you need structure in the classroom but you have to make room for flexibility to meet the needs of your students. The trees help to support this concept, since a tree has a strong structure but also has flexibility in its branches to obtain the need of sunlight. My outfits also help to support this concept. The dress is the same in each image which represents structure and professionalism, but the pants and shoes help represent flexibility since (the students) are all different.

Donna's creative arts background, admitted challenges in traditionally structured learning situations, and persistence had emerged early. I noticed her highlighted, carefully transcribed text notes. Peers could see Donna did not shy from opposing viewpoints or questioning status quo; I valued contentious class discussions, as $20 \%$ of "class participation" was evaluated in the overall course score. I imagine that Donna would laboriously have prepared written assignments but, if I weighted these along with quiz and essay scores more heavily, these forms of assessments could have easily masked Donna's depth of understanding. Instead, by creatively risk-taking, she had an ability to express fuller comprehension of course concepts and I had opportunities to assess her understanding more authentically. We both progressed in our development as teachers.

Gina was a theater education major. She was confident taking creative risks, did not require support that reluctant students need, and was comfortable with non-traditional teaching and alternative assessments. When I initially asked students to introduce each other and demonstrate multiple learning styles, it was clear Gina enthusiastically would welcome activity-based assignments to achieve course objectives. Gina described my instructional style as being "free spirited." While Gina perceived my role as the instructor as lateral to the students' process of learning, rather than central, she also repositioned how she saw herself-becoming an active, engaged learner. She observed that: 
... (I) let the process of the who, what, where, and why questioning happen first among the students. This technique gave us the room to make discoveries, or to create hypothesis. It made (us) realize that a teacher is...someone to guide us through and help us if we fall off the horse, but not to hold our hands and do the work for us...(to) let you feel comfortable exploring avenues that are unlike yourself.

I agree that my role as teacher educator positioned students intentionally to explore and connect experiences to course objectives but I have found that is not always successful and that, indeed, the difficult and real work of being a creative, constructivist, student-centered teacher does not guarantee learning outcomes-especially with students who are NOT like Gina.

Assisting students to connect text-based concepts with their prior experiences is the goal of creative processes, and the arts-based methods I use to guide their self-discovery and philosophical inquiry becomes more important, to me, than students' adoption of any one philosophy of education. Gina described how this occurred for her:

I had never really categorized my teaching methods with a philosophy, but through ...exploration ...I can now say what I am, and what I am not... (because we) tackle(d) the topics that in other classrooms maybe seem uncomfortable, but were completely valid to discuss in this classroom.

When I attempt to engage students in social justice topics, such as educational inequity, conversations and activities require risk-taking on students' and my part. I have found, that while my identity (even as a relatively junior faculty member) includes being a "boundary-pusher," many of my students (and colleagues) do not welcome this persona, philosophically or pedagogically, as easily into their experiential base.

Gina explained how she learned about boundaries teachers have to cross, though she describes realities faced by those who dare not cross them:

In my experience as a student, I see teachers afraid to get personal with their students. Personal in a professional manner. Maybe lazy to get to know them, or they do not use assignments that are relatable to the students' age-appropriate experiences or lives. In EDLS (201) assignments were being manipulated to analyze my own life experiences, and relate them to teaching strategies and situations... I had to write about six campus experiences, 
describe them, what I learned from them as a teacher, person, etc. By simply relating assignments to individuals' experiences you can engage a student more easily, especially students younger than the college level.

Gina's fear is not singular. I find, while teaching, whether raising tough topics for discussion, or sharing exemplary products that are not universally acceptable in all contexts, in public schools in particular, I sometimes crush "free spirits." I am very mindful that novice teachers will find themselves under pressure of high profile assessments, public accountability, practical and philosophical limitations-including the very real threat of job loss. It is not surprising that teachers, even those who are experienced or who have relative security in the forms of seniority and tenure, find themselves unable or reluctant to use students' (or their own) lives as bases for creative curricula. I am reminded of how Gina described the juggling she does with these philosophical ideals within her realm of experience:

In my mind creativity in the classroom involves implementing the arts into strategies and assignments in all topics... But sadly I am discovering that the idea of teaching to the individual and getting to know and understand your students and what strategies benefit them seems to fit into a category that only 'creative' teachers utilized, or constructivist teachers. This should be an implemented strategy across the board. I find it crazy that teachers do not know the names of the students that they give the grades to, or that they teach every student the exact same way, and expect them all to be successful. As a prospective teacher grades $\mathrm{K}-12$, it is easy to put myself in the shoes of a High School student because it was not too long ago I was sitting in a row of desks, like I was in some prison, while a teacher talked at me for hours. I was a C average student in High School, constantly put down by my teachers and passed on to other ones when a teacher was too lazy to really work with me, or understand me. EDLS 201 gave me insight with scenarios as well as ideas to make sure I do not become one of these teachers. Creativity is breaking the standard row of desks and having everyone physically learn in the classroom...it is encouraging thought and questions, rather then making students sit silent for hours hindering their spirit, individuality, and eagerness to make discoveries.

As an art education major, Kathy gave concrete form to Gina's pleas. Whereas Gina's active, questioning, and participatory style naturally exuded in class, Kathy's graceful character revealed itself in more measured manner. A contemplative learner, she was one, I discovered in her written autobiography, who had endured personal 
family tragedy at a very young age. As a result, Kathy channeled her expressive energy privately, reflectively, but very powerfully-on canvass and in constructed pieces. An early assignment asked students to investigate current controversial education issues; from Kathy, "homelessness" elicited an oil painting. It was apparent that any rubric I could devise (not to mention paper, series of debates, exam or essay questions) would have confined Kathy's responses to concepts centered on philosophical inquiry. By the time final evaluations arrived, I eagerly anticipated how Kathy would reveal her comprehensive conception of education principles we had explored.

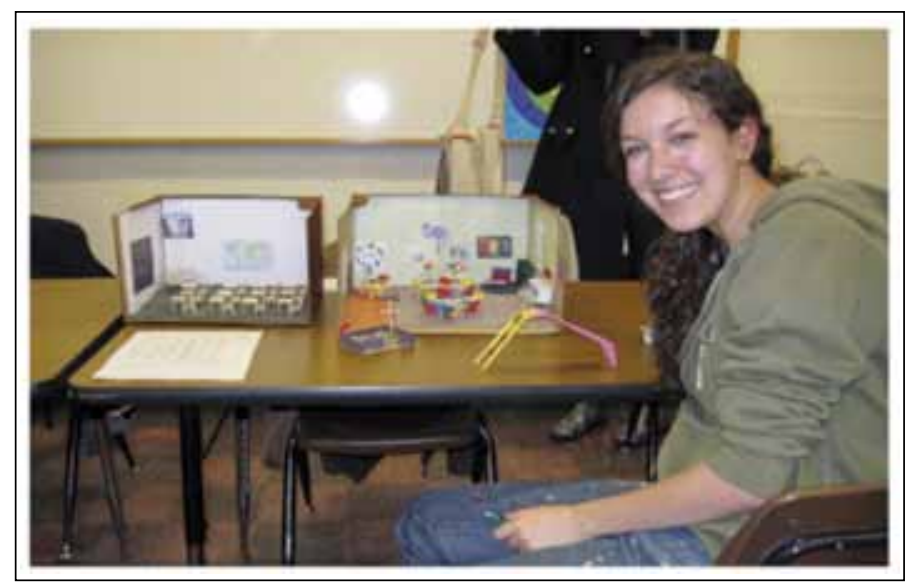

Fig. 3: Kathy Irwin - Two classrooms, May 2011

In supplemental text (required of all who choose performance options), Kathy explained:

I chose to create miniature class rooms (Fig. 3) that depicted two opposing philosophies, one that was essentialist and one that was progressive...I made by hand small wooden tables, desks, and chairs that really gave the rooms a sense of being in a class. In the progressive classroom I arranged the room so that the tables would form students into groups for discussions and projects rather than individual rows where the students couldn't speak with one another. I made a variety of work stations including, a computer station, reading corner, and a science station. This entire group-activated environment encourages students to work as a team. On the opposite room I arranged the seats in rows and tried to create a very bland non-colorful class suggesting the more traditional style class that tends to neglect the arts and focuses more on core subjects and less on the creative process. 
By creating these two rooms from scratch with my hands and my own imagination I was able to see the process by which I understood each of these philosophies and each detail that made each one unique. I was able to see visually what these ideas were about as well as show my other classmates my ideas behind the philosophies... it gave us a chance to see the principles explained in a new light.

Kathy's project was constructed simply out of cardboard and wood with meticulous attention to every facet of the learning environment. It has spawned "copycat" versions in subsequent semesters and much discussion about philosophy of education. I use the models to launch concrete experiences and to teach about abstract concepts. No student has yet articulated an analysis of the relationship between practice and theory in as great detail as Kathy did-I suspect because the other students lack the creative experience of constructing their understanding around the philosophical questions Kathy examined while choosing to think deeply, and make decisions to represent to others publically how to illustrate her understanding symbolically.

Kathy also created Invisible Boundaries (Fig. 4), which was awarded Best of Show in the SUNY system. Describing this piece, she reflected on how artistic media assists her to clarify her personal identity:

... helped me to grow as a person and has made me who I am. I use my painting and ceramics as an expressive form to communicate my emotions. During my four years at college I lost my mother to pancreatic cancer. After her death I thought that I wouldn't be able to go on. My art saved me....my theme is about confinement and strength. I depict tension within the human figure where I commonly place my figures in spaces of discomfort and claustrophobia. I use exaggeration of color, texture, mark, and gesture to really bring the figures alive with agitated raw emotion. My work is as much about the process, technique, and the style as it is about the content. The way that I express myself is by working through the layers of a work and allowing it to change and grow as the process naturally occurs. I found myself going to my work for personal therapy as well as for my grief; my artwork gave me a sense of hope and accomplishment in a place that seemed so bleak.

Kathy's creative pieces express anguish that underlies the creative professional teaching and learning persona. "It goes to show that art with true passion and feeling behind it can really resonate with others without words, but still communicate so much meaning." 


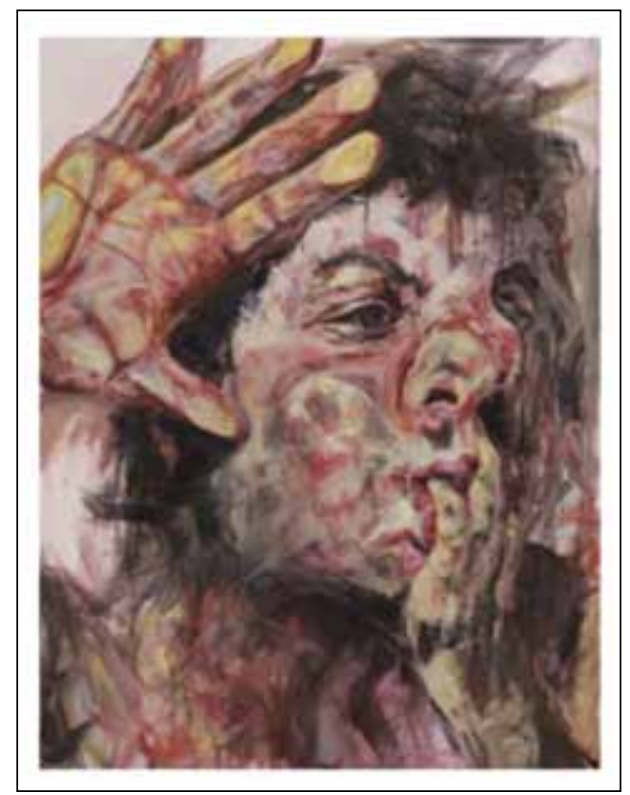

Fig. 4: Kathy Irwin - Invisible barriers

The level of detail and analysis that Kathy included in art projects submitted for EDLS 201 demonstrated deep understanding of core course concepts and far exceeded complexities I would derive from student essays submitted on traditional assignments. In using art to express her comprehension, both procedurally and in terms of content, Kathy crossed philosophical boundaries-both of knowing and of doing. She bridged theory with practice, personal with professional. Kathy concluded that:

The creative process of working on a project if it is a painting, sculpture, or a project from a non-art (i.e., EDLS 201) class allows for a sense of discovery in ideas, concepts, and feelings that one might never see from a traditional standpoint. Allowing a creative approach to any lesson allows for new boundaries to be crossed and encourages growth and risk taking. I have learned from experience that the only way to move forward is to challenge yourself and to take risks, knowing that it may not always work out the way you planned, but you will never know if you never try.

I would concur. While creative exercises in EDLS 201 (and other classes) have failed miserably (and some students have not been hesitant to let me know!), I am cognizant of my very limited formal art or theater training. I am by nature, unconfident, somewhat introverted and insecure about performance-based assessments 
myself. I, too, perseverate over mixed student comments, and wonder whether I should heed those who lobby for more lectures and quizzes, demand less passion (about social justice issues) or more specificity about "what the instructor wants" on projects. Rubrics intentionally contain broad descriptors; ultimately, my desire for retaining creative options appears to be outweighed by my concern over students' grade point averages. While I remain reluctant to spell out "creativity" indices, I am also occasionally tempted to include more perennial key content (vocabulary, for instance), because of pressure to prepare teacher education candidates for certification exams and annual performance program reviews. Requiring students to identify state department of education acronyms elicits complaints and finding creative ways to teach these essential elements eludes me. Retrospectively reviewing student comments, I wonder to what degree my philosophy and creativity have become entwined in teacher candidates' developmental processes. Attempting to evoke creativity within my students is an exercise that, ultimately, lies within each learner's prerogative-to adopt or discard this as part of their critical thinking, decision-making and philosophical inquiry practices.

\section{Conclusion}

In this article, I described decision-making processes I went through redesigning a foundational, Principles of Education course-in conjunction with my students' experiences. I outlined my own philosophy of education and how I attempt to motivate teacher education candidates using creative, learner-centered methods of instruction and assessment. Three former students also shared interpretation or examples of how they connected course content, creatively, to their own learning. We described challenges faced within our learning and teaching contexts; I suggest these may mirror those that teachers face when they attempt to implement creative pedagogy or qualitative methods of assessment, given changes occurring in New York State and U.S. education systems.

Despite my best efforts at inspiring and perspiring with my students to become a more creative thinker, teacher, and learner, I face limitations as an instructor. Taking learners' needs into account in my classes and building comfort with ambiguity are disposition cited formally in SUNY Potsdam's teacher education assessment guides; these indicate that colleagues in our institution require the freedom to take risks, as well. Allowing my students to creatively demonstrate how they process understanding of course content by actively participating in the Principles of 
Education class is, for me, the epitome of centering teaching and learning practice around philosophical inquiry. Without being placed in a forced, contrite, or trivialized state (Kenkmann, 2008), it seems the creative process ultimately requires sophisticated skills, knowledge, and an open mind-on the part of teachers and students and the community in which they learn-alike. It is one that resonated, at least to the three students whose voices are represented here. While they may have experienced relative freedom to learn in a creative environment-learning the liberating aspect of being, what Gina referred to as a "free spirit," for other students, this may not have been the case.

My experiences as a teacher educator and junior faculty member have provided a self-critical examination of how I experimented to reshape a traditional course in an undergraduate teacher education program. My former students' experiences, represented by Donna, Gina, and Kathy, show how childhood, theater, and art education students made observations of their own evolving philosophies of education. Together with my experience, we shared a collective understanding of what it means to attempt to creatively teach, learn, and serve, recognizing that we are all constrained by practical realities in the contexts where we work. Finally, questions we raised may serve to underscore for others what it means to innovatively think or add new knowledge to the field, while practicing the art of teaching.

Realities shared here have not entirely dictated my methods, and I have not returned to an essentialist or perennial core curricula. It is my hope that my teacher education candidates will, in spite of the increased emphasis on adopting and returning to scripted, commercialized, and prepared programs of instruction in school districts, also find concrete possibilities to be creative. Teacher education students arrive in classes with expectations and training to think about curriculum, classroom management, and assessment in a particular (and less creative) form. What I (and, in turn, my students) do (or choose not to do) will impact whether (or not) they are, in turn, able to become gainfully employed. Yet, the pragmatic reality of teachers' positions influences how idealistic, experiential, social reconstructionist or radically critical thinkers their students will become. This, in turn, influences how creative we practitioners want to-or are able to-become. With this in mind, I must and do, ethically and creatively, consider how to balance my philosophy with students' needs, urging them to do the same. 


\section{References}

Butler-Kisber, L. (2010). Qualitative inquiry: Thematic, narrative and arts-informed perspectives. London: Sage.

Chartock, R. (Ed.). (2004). Educational foundations: An anthology. 2nd Edition. NJ: Prentice Hall.

Chase, S.E. (2005). 'Narrative inquiry - Multiple lenses, approaches, voices,' in N.K. Denzin and Y.S. Lincoln (Eds.), The Sage handbook of qualitative research (pp. 651-679). Thousand Oaks, CA: Sage Publications.

Childhood/Early Childhood Dispositions, 2009, SUNY Potsdam (Internal document).

Cook, L.S., Smagorinsky, P., Fry, P. G., Konopak, B., \& Moore, C. (2002). Problems in developing a constructivist approach to teaching: One teacher's transition from teacher preparation to teaching. The Elementary School Journal, 102(5), 389-413.

Craft, A. (2003). The limits of creativity in education: Dilemmas for the educator. British Journal of Educational Studies, 51(2), 113-127.

Danielson, C. (2011). The framework for teaching evaluation instrument. The Danielson Group. Retrieved from www.danielsongroup.org

Denzin, N. (1989). Interpretive biography. Newbury Park, CA: Sage.

Fasko, D. J. (2000-2001). Education and creativity. Creativity Research Journal, 13(3\&4), 317-327.

Freire, P. (2005). Teachers as cultural workers. Cambridge, MA: Westview Press.

Greene, M. (1988). The dialectic of freedom. New York: Teachers College Press
Gunn, A. (2010). Practical suggestions for teaching students to think for themselves. Discourse. 4(1), 71-76. Retrieved from http://prs.heacademy.ac.uk/view. html/PrsDiscourseArticles/175

Kenkmann, A. (2008). Creativity and enjoyment in philosophy teaching: Lessons from adult education. Discourse, 7(2), 207-220. Retrieved from http://prs.heacademy. ac.uk/pdf.html/PrsDiscourseArticles/27

Kress, T. (2010). Tilting the machine: A critique of one teacher's attempts at using art forms to create postformal, democratic learning environments. Journal of Educational Controversy, 5(1). Bellingham, WA: Woodring College of Education, Western Washington University. Retrieved from http://www.wce.wwu.edu/Resources/ CEP/eJournal/v005n001/a008.shtml

NCATE, National Council for Accreditation of Teacher Education. http://www.ncate.org/

Parkay, F. W., \& Stanford, B.H. (2010). Becoming a teacher. 8th Edition. NJ: Pearson Prentice Hall.

Reagan, T. (2005). Non-western educational traditions: Indigenous approaches to educational thought and practice. 3rd Edition. NJ: Lawrence Erlbaum Associates, Inc.

Sawyer, R. K. (2006). Educating for innovation. Thinking Skills and Creativity, 1(1), 41-48.

State University of New York at Potsdam, General Education. http://www.potsdam. edu/academics/general_education/moi/ index.cfm

TaskStream, www.taskstream.com. 


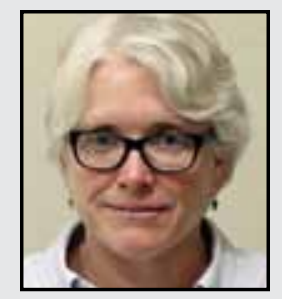

Michele Pinard is from the Adirondack Mountains. She is an intercultural educator and Associate Professor in the Department of Curriculum \& Instruction at the State University of New York at Potsdam. She supervises undergraduate and graduate student teachers in clinical settings, and teaches Childhood and Early Childhood courses. Her research interests focus on critical incidences, teacher identity development, and internationalizing the curriculum.

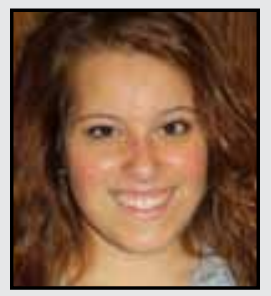

Gina Marie Bilardi comes from Long Island, New York and has performed at the Apollo Theatre, the Duplex Cabaret, and off Broadway. Inspired by working with PINK, Katherine Mcphee, Jason Robert Brown, Patrick Wilson, David Clemmons Casting, Frank Wildhorn, and Nancy Carson Casting, she has used earlier performing experiences at Long Island High School for the Arts Summer Academy and The Future Stars Summer program as a drama instructor to apply it to her current work as a senior Theatre Educator major in her current collegiate setting.

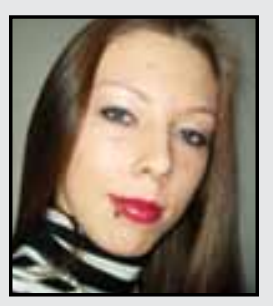

Donna Cappel was born in Hollywood, Florida, raised as an only child by a single mother, and is the first of her family members to graduate from college. She is pursuing a graduate degree at the School of Visual Arts in NYC and hopes to teach art. She credits her teachers at the Long Island High School for the Arts with inspiring her interest in student-centered teaching and in a variety of art: drawings, paintings, art history, photography, computer graphics, ceramics, and sculptural anatomy. 


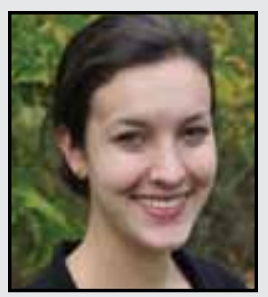

Kathy Irwin is from Oswego, New York. She received a Bachelor of Fine Arts degree with a concentration in painting and attributes her love and passion for art to her family. Both parents impressed artistic values on her, urged her to experiment, and encouraged her to get her hands dirty to explore her creative side. She believes hard work and having an open mind are two of the most important ethics in her art. 